\title{
Myoclonus and Metabolic Alkalosis from Licorice in Antacid
}

\author{
Tadashi IshiguchI, Naoya MikiTA, Takuya IwATA*, Hiroya NAKATA*, Hiroaki SATO, \\ Yuji Higashimoto, Hisashi FuJIMOTO**, Sohei YoshidA*** and Hidekazu ITOH
}

\begin{abstract}
A 90-year-old woman with hypertension developed metabolic alkalosis and myoclonus. Her medications included diltiazem hydrochloride, benidipine hydrochloride, kallidinogenase, procaterol hydrochloride, sennoside, dihydrocodeine phosphate, and $\mathrm{KM}$ powder $^{\circledR}$ antacid that contained $354 \mathrm{mg}$ of licorice and $900 \mathrm{mg}$ of sodium bicarbonate per $3.9 \mathrm{~g}$ of powder. Endocrinological studies showed slightly reduced plasma renin activity and normal plasma aldosterone concentration. A provisional diagnosis of licorice-induced metabolic alkalosis was established and the patient was successfully treated after correction of serum $\mathrm{pH}$ and cessation of the medications. Licorice-induced metabolic alkalosis must be considered in the differential diagnosis of myoclonus. (Internal Medicine 43: 59-62, 2004)
\end{abstract}

Key words: metabolic alkalosis, myoclonus, hypokalemia, licorice, glycyrrhizin, antacid

\section{Introduction}

Metabolic alkalosis is defined as an abnormal physiologic process characterized by a primary gain of strong base or loss of strong acid in the extracellular fluid (1). Although alkalosis is generally less dangerous than acidosis, severe hydrogen-ion deficit may be life threatening. Severe acute metabolic alkalosis with $\mathrm{pH}$ values above 7.55 often reduces cerebral blood flow and causes seizure and coma (2). Photomyoclonus and myoclonic-like involuntary movements were reported in states of alkalosis $(3,4)$. We describe the presentation of a 90-year-old woman who developed myoclonus

For editorial comment, see $\mathrm{p} 5$. and metabolic alkalosis after long-term ingestion of licorice contained in an antacid.

\section{Case Report}

A 90-year-old Japanese woman had been treated for hypertension at a local clinic for 20 years. Her daily oral medications on admission included diltiazem hydrochloride $\left(\right.$ Herbesser $\left.^{\circledR}\right) 90 \mathrm{mg}$, benidipine hydrochloride $\left(\right.$ Coniel $\left.^{\oplus}\right) 2$ mg, kallidinogenase (Kallikrein $\left.{ }^{\oplus}\right) 90$ IU, procaterol hydrochloride $\left(\right.$ Meptin $\left.^{\circledR}\right) 50 \mu \mathrm{g}$, sennoside $\left(\right.$ Pursennid $\left.^{\circledR}\right) 12 \mathrm{mg}$, dihydrocodeine phosphate (Codeine Phosphate ${ }^{\circledR}$ ) $30 \mathrm{mg}$, and KM powder ${ }^{\circledast}$ antacid that contained $354 \mathrm{mg}$ of licorice and $900 \mathrm{mg}$ of sodium bicarbonate per $3.9 \mathrm{~g}$ of powder. At 7:30 PM, on August 7, 2001, she was suddenly went into an attack of systemic tremor, which occurred intermittently. She visited her local clinic and temporally recovered from the attack after receiving an intravenous infusion of $500 \mathrm{ml}$ saline. On the next morning, she developed the tremor again and was referred to our hospital. She had undergone a surgical operation for hydatidiform mole 62 years ago. She had no history of diarrhea, vomiting, gastrointestinal surgery, or diuretic use. The family history was negative.

Physical examination on admission revealed body weight and height were $45 \mathrm{~kg}$ and $148 \mathrm{~cm}$, respectively and body temperature of $37.5^{\circ} \mathrm{C}$. The blood pressure was $142 / 70$ $\mathrm{mmHg}$ and pulse rate was regular at 90 beats/min. Her palpebral conjunctiva was slightly anemic, but bulbar conjunctiva did not appear jaundiced. Heart and respiratory sounds were normal. There were no significant findings on abdominal examination and there was no peripheral edema. Neurological physical examination found systemic myoclonus. A chest X-ray examination showed the presence of cardiac dilatation (cardiothoratic ratio: 54.2\%). Echocardiography showed mild mitral regurgitation and left atrial dilatation.

Laboratory findings on admission indicated the presence

From Department of Internal Medicine, Wakayama Medical University Kihoku Hospital, Wakayama, *the Second Department of Internal Medicine, Wakayama Medical University, Wakayama, **Department of Emergency and Critical Care Medicine, Wakayama Medical University, Wakayama and $* * *$ Kansai College of Oriental Medicine, Osaka

Received for publication December 9, 2002; Accepted for publication August 15, 2003

Reprint requests should be addressed to Dr. Tadashi Ishiguchi, Department of Internal Medicine, Wakayama Medical University Kihoku Hospital, 219 Myoji, Katsuragi-cho, Ito-gun, Wakayama 649-7113 
ISHIGUCHI et al

Table 1. Laboratoy Data (August 8, 2001)

\begin{tabular}{|c|c|c|c|c|c|}
\hline \multicolumn{2}{|l|}{ Urinalysis } & \multicolumn{4}{|c|}{ Serology } \\
\hline Protein & $(-)$ & ESR & $83 \mathrm{~mm} / \mathrm{h}$ & $\mathrm{Na}$ & $138 \mathrm{mmol} /$ \\
\hline Sugar & $(-)$ & CRP & $6.0 \mathrm{mg} / \mathrm{dl}$ & $\mathrm{K}$ & $2.5 \mathrm{mmol} / \mathrm{l}$ \\
\hline \multirow[t]{2}{*}{ Occult blood } & $(-)$ & & & $\mathrm{Cl}$ & $77 \mathrm{mmol} / \mathrm{l}$ \\
\hline & & \multicolumn{2}{|c|}{ Serum Biochemistry } & $\mathrm{Ca}$ & $6.2 \mathrm{mg} / \mathrm{dl}$ \\
\hline \multicolumn{2}{|l|}{ Hematology } & AST & $63 \mathrm{IU} / l$ & IP & $3.5 \mathrm{mg} / \mathrm{dl}$ \\
\hline $\mathrm{RBC}$ & $306 \times 10^{4} / \mu 1$ & ALT & $20 \mathrm{IU} / l$ & $\mathrm{Mg}$ & $0.8 \mathrm{mg} / \mathrm{dl}$ \\
\hline $\mathrm{Hb}$ & $9.2 \mathrm{~g} / \mathrm{dl}$ & $\mathrm{LDH}$ & $974 \mathrm{IU} / l$ & $\mathrm{TP}$ & $6.5 \mathrm{~g} / \mathrm{dl}$ \\
\hline $\mathrm{Ht}$ & $27 \%$ & ALP & $20 \mathrm{IU} / l$ & Alb & $3.0 \mathrm{~g} / \mathrm{dl}$ \\
\hline WBC & $15,590 / \mu \mathrm{l}$ & CPK & $3,260 \mathrm{IU} / \mathrm{l}$ & FBS & $91 \mathrm{mg} / \mathrm{dl}$ \\
\hline \multirow{2}{*}{\multicolumn{2}{|c|}{$\begin{array}{l}\text { Stab } 0, \text { Seg } 83, \text { Eos } 0 \text {, } \\
\text { Baso } 0, \text { Mon } 5 \text {, Lym } 12 \%\end{array}$}} & $\gamma$-GTP & $8 \mathrm{IU} / l$ & & \\
\hline & & BUN & $17.1 \mathrm{mg} / \mathrm{dl}$ & & \\
\hline Platelet & $51.8 \times 10^{4} / \mu 1$ & $\mathrm{Cr}$ & $1.5 \mathrm{mg} / \mathrm{dl}$ & & \\
\hline
\end{tabular}

of an acute inflammatory reaction (leukocyte count: $15,590 / \mathrm{mm}^{3}$, C-reactive protein (CRP): $6.0 \mathrm{mg} / \mathrm{dl}$, erythrocyte sedimentation rate (ESR): 83 and $125 \mathrm{~mm}$ on the first and second hour, respectively). Biochemical analysis showed an elevated creatine phosphokinase (CPK) level, hypokalemia, hypochlolemia, hypocalcemia, hypomagnesemia (Table 1). A spinal tap examination and culture of spinal fluid showed normal findings. There were no other findings suggestive of a focus of bacterial infection elsewhere. Arterial blood gas analysis revealed severe metabolic alkalosis $\left(\mathrm{pH}\right.$ 7.579, $\mathrm{PCO}_{2}$ 50.5 Torr, $\mathrm{Po}_{2}$ 53.6 Torr, $\mathrm{HCO}_{3}{ }^{-} 47.4$ $\mathrm{mEq} / l$, base excess $21.8 \mathrm{mEq} / l$, saturation of oxygen $93.7 \%$ ). Endocrinological studies showed a slightly reduced plasma renin activity (PRA) and normal plasma aldosterone concentration (PAC) (Table 2). There were no other remarkable endocrine findings. An abdominal computed tomography (CT) did not show swelling of the adrenal gland or tumorous lesions. Twenty-four-hour urinary collections showed renal potassium wasting (Fig. 1). Urine calcium, phosphate, and magnesium levels on August 13, 2001 were $78 \mathrm{mg} /$ day (100-300), $37 \mathrm{mg} /$ day (500-2,000), and $20 \mathrm{mg} /$ day (20$130)$, respectively (normal limits).

Since the patient had been given a licorice-containing agent for a long period and other endocrinological studies found no abnormality, she was diagnosed as licorice-induced metabolic alkalosis. To correct the $\mathrm{pH}$ value, an $\mathrm{NH}_{4} \mathrm{Cl}$ solution and saline were administered. Intravenous calcium gluconate and potassium chloride were given to normalize serum electrolyte levels (Fig. 1). Metabolic alkalosis and serum electrolyte abnormalities were corrected within two weeks and intravenous solutions were tapered (Fig. 1). Myoclonus completely disappeared after correction of the acid-base balance.

\section{Discussion}

Metabolic alkalosis is a primary pathophysiologic event characterized by the gain of bicarbonate or the loss of nonvolatile acid from extracellular fluid (5). Many disorders seen in clinical practice may lead to the development of metabolic alkalosis. Only a few of these, such as loss of gastric fluid, aggressive diuretic therapy, and hyperadrenocorticism associated with neoplasm result in extreme alkalosis (plasma bicarbonate grater than $50 \mathrm{mEq} / l$ ) (6). Although alkalosis is generally less dangerous than acidosis, severe hydrogen-ion deficit may be life threatening. Metabolic alkalosis is generally considered severe if $\left[\mathrm{HCO}_{3}^{-}\right]$exceeds $40-42 \mathrm{mmol} / \mathrm{l}$ and treatment is mandatory (7). Severe acute metabolic alkalosis with $\mathrm{pH}$ values above 7.55 often reduces cerebral blood flow and causes seizures and coma (2).

In this case urine chloride levels were more than 20 $\mathrm{mEq} / \mathrm{l}$ and plasma renin and aldosterone levels were low. According to an algorithmic approach, combined clinical problem solving for hypokalemia accompanied by an acidbase disturbance, the differential diagnosis was narrowed to licorice ingestion, Cushing's syndrome, the hydroxylase deficiencies, or Liddle's syndrome (8). Although blood pressure of the present case during admission was normal, she apparently had been on licorice-containing medicine for a long time. Endocrinological studies excluded the possibility

Table 2. Endocrinological Data

\begin{tabular}{lrrr}
\hline Plasma renin activity & $0.2 \mathrm{ng} / \mathrm{ml} / \mathrm{h}$ & $(0.3-2.9)$ & 9. Aug. 01 \\
Plasma aldosterone concentration & $43 \mathrm{pg} / \mathrm{ml}$ & $(29.9-159)$ & 9. Aug. 01 \\
Plasma cortisol & $19.1 \mathrm{mg} / \mathrm{dl}$ & $(4.0-18.3)$ & 9. Aug. 01 \\
Urine 17-KS & $2.3 \mathrm{mg} / \mathrm{day}$ & $(2.4-11.0)$ & 13. Aug. 01 \\
Urine 17-OHCS & $4.4 \mathrm{mg} / \mathrm{day}$ & $(2.2-7.3)$ & 13. Aug. 01 \\
\hline
\end{tabular}

17-KS: 17-ketosteroids, 17-OHCS: 17-hydroxycorticoids, (normal limits). 
Metabolic Alkalosis and Myoclonus

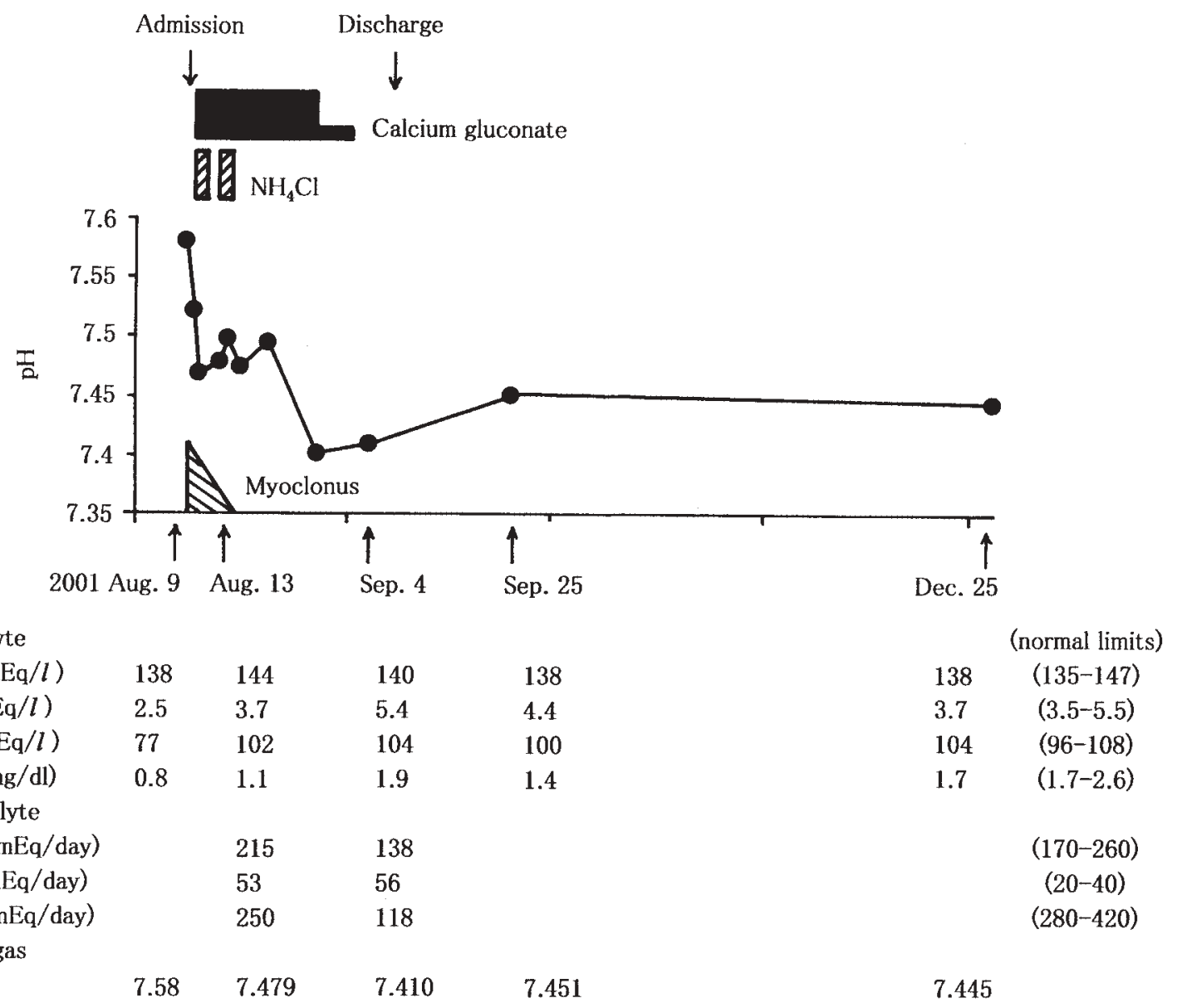

Figure 1. Clinical course. Myoclonus disappeared after acid-base balance correction.

of Cushing's syndrome and the hydroxylase deficiencies. Liddle's syndrome was also excluded because plasma renin and aldosterone levels were not suppressed and her acid-base balance was maintained normal without any medication after cessation of licorice-ingestion.

Biochemical analysis of the present case showed hypokalemia, hypochlolemia, hypocalcemia, and hypomagnesemia. Twenty-four-hour urinary collections revealed renal potassium wasting. Spot urine chloride was more than 20 $\mathrm{mEq} / \mathrm{l}$ and plasma renin and aldosterone levels were low and normal, respectively. It is known that licorice ingestion results in hypokalemic metabolic alkalosis. The compound impairs the action of the enzyme 11-beta-hydroxysteroid dehydrogenase that converts cortisol to cortisone in aldosterone-responsive tissues such as the collecting tubules in the kidney (5). Therefore cortisol is allowed to occupy type I renal mineralcorticoid receptors, mimicking aldosterone (9). We speculate the cause of hypomagnesemia may be attributed to pseudoaldosterism induced by licorice. In this case, it is unclear why the patient had suddenly developed metabolic alkalosis after medication of licorice for 20 years. It is conceivable that dehydration enhanced reabsorption of bicarbonate at the proximal tubules, resulting in developing metabolic alkalosis.

Myoclonus is defined as sudden, brief, shock-like, involuntary movements caused by muscular contractions or inhibitors (10). It is a symptom that occurs in a wide variety of metabolic and neurologic disorders. However, to our knowledge only one case was reported as myoclonus with metabolic alkalosis (11). Okada et al suggested that metabolic alkalosis is the etiology of myoclonus. Although the mechanism of myoclonus induced by metabolic alkalosis is still unclear, it is known that severe metabolic alkalosis can lower the seizure threshold (11). It is apparent that severe metabolic alkalosis in this case played an important role in the development of myoclonus. On the other hand, laboratory data of the patient showed hypomagnesemia during myoclonus and after normalization of serum magnesium levels myoclonus disappeared. Therefore, it is also possible that hypomagnesemia induced myoclonus. Although the pathophysiology of hypomagnesemic seizures remains unclear, hypomagnesemia has been reported as an uncommon cause of seizures especially in infants and neonates (12). In this case the laboratory data on admission showed increased 


\section{ISHIGUCHI et al}

leukocyte counts and elevated serum CPK and CRP levels. Temporal elevation of serum CPK level is demonstrated in epileptic and nonepileptic seizure patients. It is reported that convulsions produce changes in muscle tissue membranes that persist for three to eight days and result in CPK leakage into plasma and extracellular fluid (13). On the other hand, it is known that activation of inflammation may occur after epileptic seizures without any evidence of systemic or central nervous system infection (14). According to Peltola et al, production of interleukin-6 (IL-6) in the central nervous system can stimulate increased production of IL-6 in peripheral blood, which subsequently activates the acute phase reaction (14). The acute phase reaction in this case may be explained by this mechanism.

In conclusion, we described a 90-year-old woman with severe metabolic alkalosis and myoclonus. The physician must consider the possible ingestion of licorice contained antacid, like KM powder ${ }^{\circledR}$ in the different diagnosis of metabolic alkalosis.

\section{References}

1) Martin WJ, Matzke GR. Treating severe metabolic alkalosis. Clin Pharm 1: 42-48, 1982.

2) Fraley DS, Adler S, Bruns F. Life-threatening metabolic alkalosis in a comatose patient. South Med J 72: 1024-1025, 1979.

3) Adachi M, Ikemoto Y, Kubo K, Takuma C. Seizure-like movements during induction of anaesthesia with sevoflurane. Br J Anaesth 68: 214-215, 1992.

4) Victor M. The role of hypomagnesemia and respiratory alkalosis in the genesis of alcohol-withdrawal symptoms. Ann N Y Acad Sci 215: 235 248, 1973

5) Khanna A, Kurtzman NA. Metabolic alkalosis. Respir Care 46: 354365, 2001.

6) Kassirer JP. Serious acid-base disorders. N Engl J Med 291: 773-776, 1974.

7) Abelow B. Understanding acid-base. 1st. ed. Williams \& Wilkins, Baltimore, 1997: 299-305.

8) Bartholow C, Whittier FC, Rutecki GW. Hypokalemia and metabolic alkalosis: algorithms for combined clinical problem solving. Compr Ther 26: 114-120, 2000.

9) Edwards CR, Stewart PM, Burt D, et al. Localisation of 11 betahydroxysteroid dehydrogenase--tissue specific protector of the mineralocorticoid receptor. Lancet 2: 986-989, 1988.

10) Caviness JN. Myoclonus. Mayo Clin Proc 71: 679-688, 1996.

11) Okada K, Kono N, Kobayashi S, Yamaguchi S. Metabolic alkalosis and myoclonus from antacid ingestion. Intern Med 35: 515-516, 1996.

12) Weisleder P, Tobin JA, Kerrigan JF 3rd, Bodensteiner JB. Hypomagnesemic seizures: case report and presumed pathophysiology. J Child Neurol 17: 59-61, 2002.

13) Wyllie E, Lueders H, Pippenger C, VanLente F. Postictal serum creatine kinase in the diagnosis of seizure disorders. Arch Neurol 42: 123-126, 1985.

14) Peltola J, Laaksonen J, Haapala AM, Hurme M, Rainesalo S, Keranen T. Indicators of inflammation after recent tonic-clonic epileptic seizures correlate with plasma interleukin-6 levels. Seizure 11: 44-46, 2002 